\title{
The poor insane Ophelia: reconsidering Ophelia syndrome
}

\author{
La pobre e insensata Ofelia: reconsiderando el síndrome de Ofelia \\ Carlos A. SOTO-RINCÓN¹, Sergio A. CASTILLO-TORRES', Diego A. CANTÚ-GARCÍA1', Ingrid ESTRADA- \\ BELLMANN ${ }^{1}$, Beatriz CHÁVEZ-LUÉVANOS' ${ }^{1}$, Alejandro MARFIL'1
}

\begin{abstract}
The association between memory loss and Hodgkin's lymphoma has been given the eponym of Ophelia syndrome, in memory of Shakespeare's character in The Tragedy of Hamlet, Prince of Denmark. Nevertheless, there are differences between the disease and the character. Objective: To review the origins and uses of the eponym through an original article by pathologist lan Carr, its relation to the character Ophelia, and the related autoantibodies. Methods: Historical narrative review. Results: Besides an eloquent description in the original article, Carr presaged the presence of autoantibodies, before they had been thoroughly researched. Since then, five different autoantibodies (mGluR5, Hu, NMDAR, SOX, PCA2) have been associated with Hodgkin's disease. It is interesting to note the divergent outcomes of Shakespeare's character and the patient in the original description by Carr, the latter recovering to lead a normal life, and the former deceased. Conclusions: Although there is little relationship between the fictional character and the syndrome, both imply the unintentional trigger of self-harm (suicide in one case, autoimmunity in the other), thus remaining associated.
\end{abstract}

Keywords: Limbic encephalitis; Hodgkin disease.

\section{RESUMO}

El síndrome de Ofelia describe la asociación entre pérdida de memoria y enfermedad de Hodgkin, en memoria del personaje de La Tragedia de Hamlet, Príncipe de Dinamarca, de William Shakespeare. Sin embargo, existen diferencias entre ambos. Objetivo: Revisar los orígenes y usos del epónimo a través del artículo original, su relación con el personaje y los autoanticuerpos relacionados. Métodos: Revisión narrativa histórica. Resultados: Además de una descripción elocuente, el artículo original prefigura los autoanticuerpos, cuando no se buscaban de rutina. Desde entonces, cinco distintos (mGluR5, Hu, NMDAR, SOX, PCA2) han sido asociados. Cabe destacar, que el desenlace del personaje y del paciente fueron diametralmente opuestos, el primero falleció y el segundo se recuperó, llevando una vida normal. Conclusiones: A pesar de la poca relación entre el personaje y el síndrome, ambos implican el desencadenamiento no intencional de daño auto-inflingido (suicidio en un caso, autoinmunidad en el otro), manteniendo así la adecuacía.

Palavras-chave: Encefalitis límbica; enfermedad de Hodgkin.

"To be, or not to be, that is the question:

Whether 'tis nobler in the mind to suffer

The slings and arrows of outrageous fortune,

Or to take arms against a sea of troubles,

And by opposing, end them. To die, to sleep-

No more, and by a sleep to say we end

The heart-ache and the thousand natural shocks

That flesh is heir to; 'tis a consummation

Devoutly to be wish'd. To die, to sleep-

To sleep, perchance to dream"

- Hamlet, Act 3, Scene 1, Lines 56-65.
In 1982, the pathologist Ian Carr wrote one of the most eloquent descriptions of disease during the suffering of his daughter Jane, as she gradually lost her memory and was eventually diagnosed with Hodgkin's disease ${ }^{1}$. Two remarkable things can be derived from Carr's article: his presaging of neuronal autoantibodies before the first association between autoantibodies and limbic encephalitis had been made ${ }^{2}$, and giving memory loss secondary to Hodgkin's disease, the eponym "Ophelia syndrome", in reminiscence of Shakespeare's character, Ophelia, in Hamlet. The Bard's plays have captivated neurologists and psychiatrists, with a recent review suggesting he was a Renaissance

\footnotetext{
'Universidad Autonoma de Nuevo Leon, Hospital Universitario “Dr. José E. González", Servicio de Neurología, Monterrey, NL, Mexico.

Carlos A. Soto-Rincón (iD) https://orcid.org/0000-0001-9355-9716; Sergio A. Castillo-Torres iD https://orcid.org/0000-0002-4727-2535

Correspondence: Sergio A. Castillo-Torres; Servicio de Neurología do Hospital Universitario “Dr. José E. González" da Universidad Autonoma de Nuevo Leon; Madero y Gonzalitos S/N, Col. Mitras Centro; 64460 Monterrey, Nuevo León, México; E-mail: sergio.castillotr@uanl.edu.mx

Conflict of interest: There is no conflict of interest to declare.

Disclosures: An abstract titled "Ophelia syndrome revisited" derived from this manuscript was presented (Poster Session P4, May $8^{\text {th }}$ ) at the 71st Annual Meeting of the American Academy of Neurology (Philadelphia PA, May 4-7, 2019).

Received 30 October 2018; Received in final form 14 February 2019; Accepted 09 April 2019.
} 
neurologist ${ }^{3}$. However, the different outcomes of Carr's description and Shakespeare's character cast doubt about the appropriateness of the eponym, which led us to review the origins of this eponym.

\section{HAMLET'S OPHELIA}

In The Tragedy of Hamlet, Prince of Denmark ${ }^{4}$, William Shakespeare presents us with a distracted Ophelia, "divided from herself and her fair judgement" (Act 4, Scene 5, Line 84; from here on 4.5.84). Previously sound of mind, gentle and loving, Ophelia obeys her father Polonius's orders of rejecting Hamlet's proposals (3.1.117), a situation that paradoxically sets in motion the very circumstances that will conclude with the slaying of Polonius by Hamlet's sword (3.4.24; Figure 1). As a consequence of "the poison of deep grief", originated from her father's death (4.5.74-75), Ophelia gets lost in a singing madness:

\section{"He is dead and gone, lady, \\ He is dead and gone, \\ At his head a grass-green turf, \\ At his heels a stone." (4.5.29-32)}

This madness leads to her death after falling in the mourning river, while "she chaunted snatches of old lauds, as one incapable of her own distress" (4.7.175-78). Until her water-filled clothing "pull'd the poor wretch from her melodies lay to muddy death"(4.7.181-83; Figure 2). Thus, the bard offers us one of the eeriest suicides in literature, as the poor insane Ophelia dies by her own hand, albeit unknowingly.

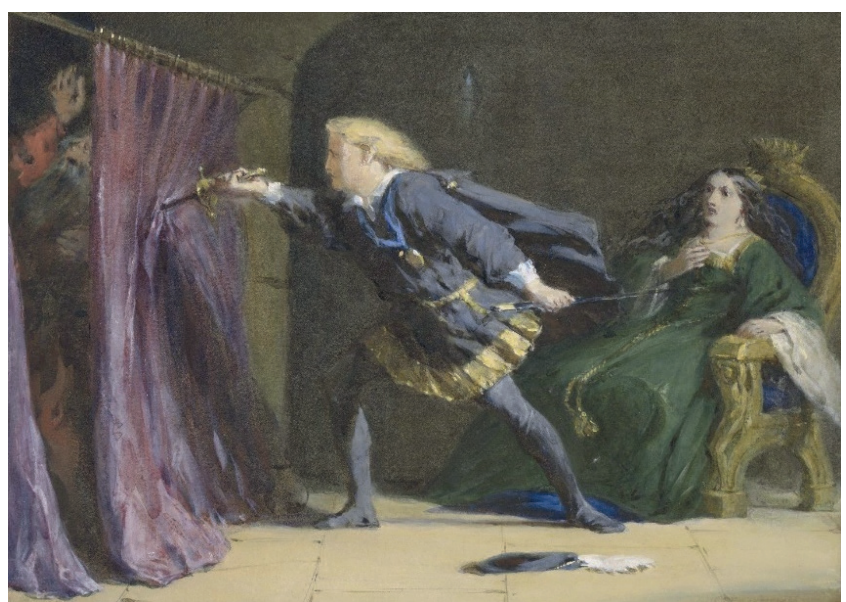

Legend:

Hamlet: How now? A rat? Dead, for a ducat, dead! Kills Polonius through the arras.

Polonius: 0, I am slain.

Act 3, Scene 4, Lines 23-24

Disclaimer:

This image is in the public domain.

Obtained from: https://en.wikipedia.org/wiki/File:Hamlet_stabs_Polonius.jpg

Figure 1. Hamlet stabs Polonius, by Coke Smyth.

\section{CARR'S OPHELIA AND ITS IMPACT}

While Dr Carr narrates his daughter's journey and is reminded of Shakespeare's Ophelia, he suggests that "there is perhaps a circulating neurotransmitter-like molecule produced by the neoplasm", thus presaging the presence of autoantibodies, which were reported four years later ${ }^{2}$, and related to the Ophelia syndrome eight years after Carr's article ${ }^{5}$. Since then, the association between memory loss and Hodgkin's disease, which we now call paraneoplastic limbic encephalitis, has been widely acknowledged as the Ophelia syndrome ${ }^{6}$.

\section{OPHELIA'S COMPLEX}

Another occurrence of Ophelia's name was described by French philosopher Gaston Bachelard, as the Ophelia complex in his book L'Eau et les rêves ${ }^{7}$, as a symbol of feminine suicide, destined to end her life in the water. In this complex, the water plays a fundamental role, as Bachelard's writes: "L'eau est l'élément de la mort jeune et belle, de la mortfleurie, et, dans les drames de la vie et de la littérature, elle est l'élément de la mort sans orgueil ni vengeance, du suicide masochiste" [Water is the element of young and beautiful death, of blooming death, and in the dramas of life and literature, it is the element of death without pride or revenge, masochistic suicide]. Although quite poetic, we could not find any references to the Ophelia complex in the medical literature.

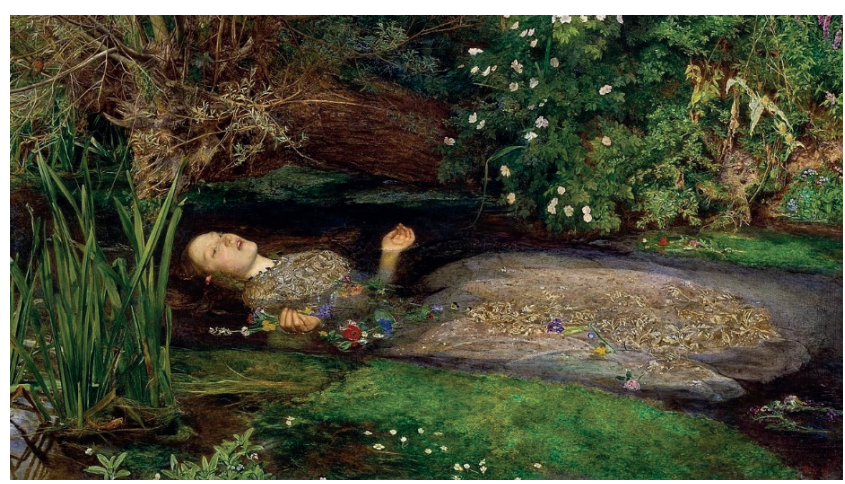

Legend:

"There on the pendant boughs her crownet weeds

Clamb'ring to gang, an envious silver broke,

When down her weedy trophies and herself

Fell in the weeping brook. Her clothes spread wide,

And mermaid-like awhile they bore her up,

Which time she chaunted snatches of old lauds,

As one incapable of her own distress,

Or like a creature native and indued

Unto that element. But long it could not be

Till that her garments, heavy with their drink,

Pull'd the poor wretch from her melodius lay

To muddy death".

Act 4, Scene 7, Lines 172-183.

Disclaimer:

This image is in the public domain

Obtained from: https://en.wikipedia.org/wiki/File:John_Everett_Millais_-_

Ophelia_-_Google_Art_Project.jpg

Figure 2. Ophelia, by John Everett Millais. 
Table. Ophelia syndrome case report series.

\begin{tabular}{|c|c|c|c|}
\hline Reference & Auto-antibody & Comments & Outcome \\
\hline \multirow{2}{*}{ Lancaster et al. ${ }^{6}$} & \multirow{2}{*}{ Anti-mGluR5 } & 46-year-old female & Recovery \\
\hline & & 15-year-old male & Recovery \\
\hline Mat et al.? & Anti-mGluR5 & 35-year-old male & Recovery \\
\hline Prüss et al. ${ }^{8}$ & Anti-mGluR5 & 30-year-old female ${ }^{*}$ & Recovery \\
\hline Hentschke $^{9}$ & Anti-Hu & 61-year-old male & Partial recovery \\
\hline Laffon $^{10}$ & Anti-Hu & 62-year-old male & Recovery \\
\hline \multirow[t]{2}{*}{ Zandi ${ }^{11}$} & Anti-NMDAR & 49-year-old male & Recovery \\
\hline & Anti-SOX1 & 17-year-old male & \\
\hline \multirow[t]{2}{*}{ Kunstreich ${ }^{12}$} & Anti-PCA2 & (Anti-SOX1 at presentation, & Not specified, with sequelae \\
\hline & & Anti-PCA2 after seven months) & \\
\hline
\end{tabular}

\section{DISCUSSION}

Dr Carr's daughter never committed suicide, nor was she involved in an event related to water (Bachelard's Ophelia complex); a situation that made one of the authors (CASR) wonder about the appropriateness of the name, having found a blog entry under the provoking title "When Shakespeare meets neurology", which briefly addressed the topic ${ }^{8}$; while another author (SACT) re-explored Hamlet in search of clues that might reinforce the association. While we could not find a direct relationship between Carr's daughter and Ophelia, because of the different outcomes, Dr Carr concluded: "In summary, recent memory loss may rarely be due to Hodgkin's disease, probably as a paraneoplastic event. It may be reversible and can be remembered as the Ophelia syndrome ${ }^{1}$.

What did Dr Carr see in his daughter that reminded him of Ophelia? We suggest her innocence made mad by an external factor (lymphoma, in this case), with him watching from afar-through a glass-as Ophelia was seen through the waters in which her life ended, by an external factor (her father's death). We can picture him wondering-as Laertes did-if "is't possible a young maid's wits should be mortal as an old man's life" (4.5.159-60), having to endure such a difficult test. In the end, Dr Carr decides-as Hamlet declares-to "take arms against a sea of troubles, and by opposing, end them" (3.1.59-60). It can be concluded that, in both cases-however divergent the outcomes-mental soundness is lost because of an external agent set in motion by themselves: Ophelia's rejection of Hamlet leads to him killing her father, and Carr's daughter's lymphoma leads her immune system to produce autoantibodies. Amidst all the "sea of troubles", Dr Carr manages, as described by the great Argentinian writer Jorge Luis Borges, "to make of the miserable circumstance of our life, things eternal or that aspire to be $e^{9}$.

As Carr predicted, a number of "circulating neurotransmitter-like molecules"-which we now call antineuronal autoantibodies-have been identified in patients with limbic encephalitis and Hodgkin's disease: anti-mGluR5 ${ }^{10-12}$; anti-Hu ${ }^{13,14}$; anti-NMDAr ${ }^{15}$; anti-SOX1 and anti-PCA2 ${ }^{16}$ (detailed in Table). Although in many other patients they have not been found, in almost all patients, tumor-directed therapy improves the neurologic syndrome.

Although initially we intended to propose changing the eponym to Carr's syndrome, to praise his accurate observations and prediction of autoantibodies; yet, as it correlates with the pathophysiology of the syndrome, perhaps it should still be remembered as the Ophelia syndrome.

\section{Acknowledgments}

The authors acknowledge Dr Ian Carr, author of the original description, for his patience and kindness in answering our doubts regarding the eponym.

\section{References}

1. Carr I. The Ophelia syndrome: memory loss in Hodgkin's disease. Lancet. 1982 Apr;1(8276):844-5. https://doi.org/10.1016/S0140-6736(82)91887-6

2. Dhib-Jalbut S, Liwnicz BH. Immunocytochemical binding of serum IgG from a patient with oat cell tumor and paraneoplastic motoneuron disease to normal human cerebral cortex and molecular layer of the cerebellum. Acta Neuropathol. 1986;69(1-2):96-102. https://doi.org/10.1007/BF00687044

3. López-Valdés JC, Miranda-Hernández A, Medina-Medina JA. [Implicaciones psiquiátricas y neurológicas en la literatura shakespeariana. Breve análisis]. Gac Med Mex. 2018;154(5):613-6. Spanish. https://doi.org/10.24875/GMM.17003332 
4. Shakespeare W, Edwards P. Hamlet, Prince of Denmark. New York: Cambridge University Press; 2003.

5. Bakheit AM, Kennedy PG, Behan PO. Paraneoplastic limbic encephalitis: clinico-pathological correlations.J Neurol Neurosurg Psychiatry. 1990 Dec;53(12):1084-8. https://doi.org/10.1136/jnnp.53.12.1084

6. Pfliegler G, Pósán E, Glaub D, Telek B, Rak K. Hodgkin's disease and memory loss: another case of the Ophelia syndrome. Br J Haematol. 1990 Feb;74(2):232. https://doi.org/10.1111/j.1365-2141.1990.tb02571.x

7. Bachelard G. L'Eau et les rêves: essai sur l'imagination de la matière. Paris: Librairie José Corti; 1942.

8. Imam I. When Shakespeare meets neurology: Hamlet, Ophelia and autoimmune encephalitis. Neurol Lounge. 2017 June 24 [cited 2019 February 19]. Available from: https://theneurologylounge.com/tag/ ophelia-syndrome/

9. Borges JL. La ceguera. In: Borges JL. Siete noches. Buenos Aires: Sudamericana; 2011. (Obras Completas, Vol 3). p. 301-11.

10. Lancaster E, Martinez-Hernandez E, Titulaer MJ, Boulos M, Weaver S, Antoine JC, et al. Antibodies to metabotropic glutamate receptor 5 in the Ophelia syndrome. Neurology. 2011 Nov;77(18):1698-701. https://doi.org/10.1212/WNL.0b013e3182364a44

11. Mat A, Adler H, Merwick A, Chadwick G, Gullo G, Dalmau JO, et al. Ophelia syndrome with metabotropic glutamate receptor 5 antibodies in CSF. Neurology. 2013 Apr;80(14):1349-50. https://doi.org/10.1212/WNL.0b013e31828ab325

12. Prüss H, Rothkirch M, Kopp U, Hamer HM, Hagge M, Sterzer P, et al. Limbic encephalitis with mGluR5 antibodies and immunotherapy-responsive prosopagnosia. Neurology. 2014 Oct;83(15):1384-6. https://doi.org/10.1212/WNL.0000000000000865

13. Hentschke S, Malzfeldt E, Salwender HJ, Braumann D, Stang A, Hentschke M. Hu-antibody positive limbic encephalitis in a patient with Hodgkin lymphoma. Leuk Lymphoma. 2008 Dec;49(12):2374-6. https://doi.org/10.1080/10428190802419657 PMID:19052989

14. Laffon M, Giordana C, Almairac F, Benchetrit M, Thomas P. Anti-Hu-associated paraneoplastic limbic encephalitis in Hodgkin lymphoma. Leuk Lymphoma. 2012 Jul;53(7):1433-4. https://doi.org/10.3109/10428194.2011.645211

15. Zandi MS, Irani SR, Follows G, Moody AM, Molyneux P, Vincent A. Limbic encephalitis associated with antibodies to the NMDA receptor in Hodgkin lymphoma. Neurology. 2009 Dec;73(23):2039-40. https://doi.org/10.1212/WNL.0b013e3181c55e9b

16. Kunstreich M, Kreth JH, Oommen PT, Schaper J, Karenfort M, Aktas O, et al. Paraneoplastic limbic encephalitis with SOX1 and PCA2 antibodies and relapsing neurological symptoms in an adolescent with Hodgkin lymphoma. Eur J Paediatr Neurol. 2017 Jul;21(4):661-5. https://doi.org/10.1016/j.ejpn.2017.03.005 